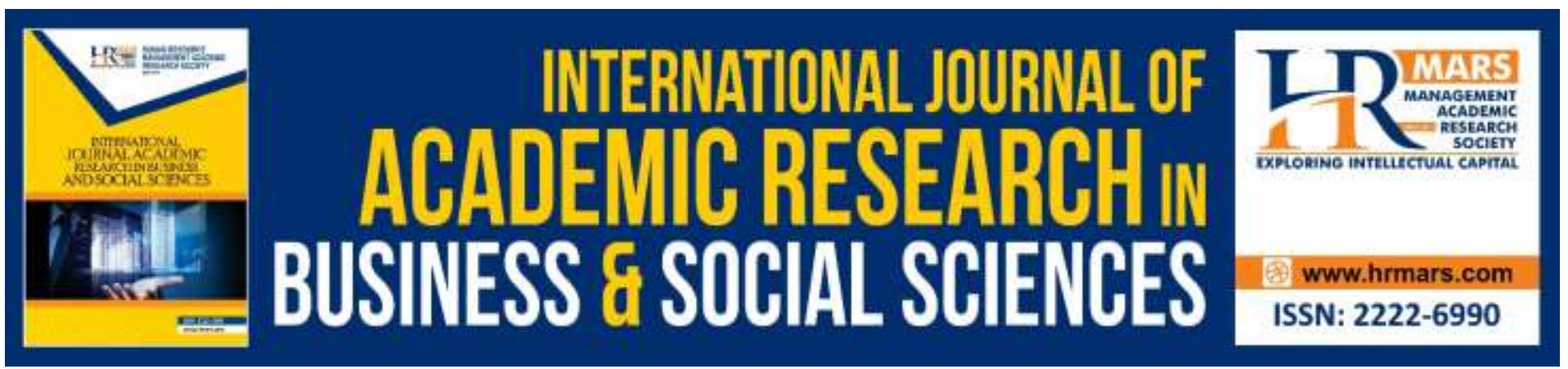

\title{
Self-Employment and Unemployment in Tunisia: Application of the ARDL Approach
}

\author{
Chiraz Feki, Sirine Mnif
}

To Link this Article: http://dx.doi.org/10.6007/IJARBSS/v9-i7/6217

DOI: $10.6007 /$ IJARBSS/v9-i7/6217

Received: 25 May 2019, Revised: 20 June 2019, Accepted: 01 July 2019

Published Online: 24 July 2019

In-Text Citation: (Feki \& Mnif, 2019)

To Cite this Article: Feki, C., \& Mnif, S. (2019). Self-Employment and Unemployment in Tunisia: Application of the ARDL Approach. International Journal of Academic Research in Business and Social Sciences, 9(7), 12001211.

Copyright: (C) 2019 The Author(s)

Published by Human Resource Management Academic Research Society (www.hrmars.com)

This article is published under the Creative Commons Attribution (CC BY 4.0) license. Anyone may reproduce, distribute, translate and create derivative works of this article (for both commercial and non-commercial purposes), subject to full attribution to the original publication and authors. The full terms of this license may be seen

at: http://creativecommons.org/licences/by/4.0/legalcode

\section{Vol. 9, No. 7, 2019, Pg. 1200 - 1211}

Full Terms \& Conditions of access and use can be found at http://hrmars.com/index.php/pages/detail/publication-ethics 


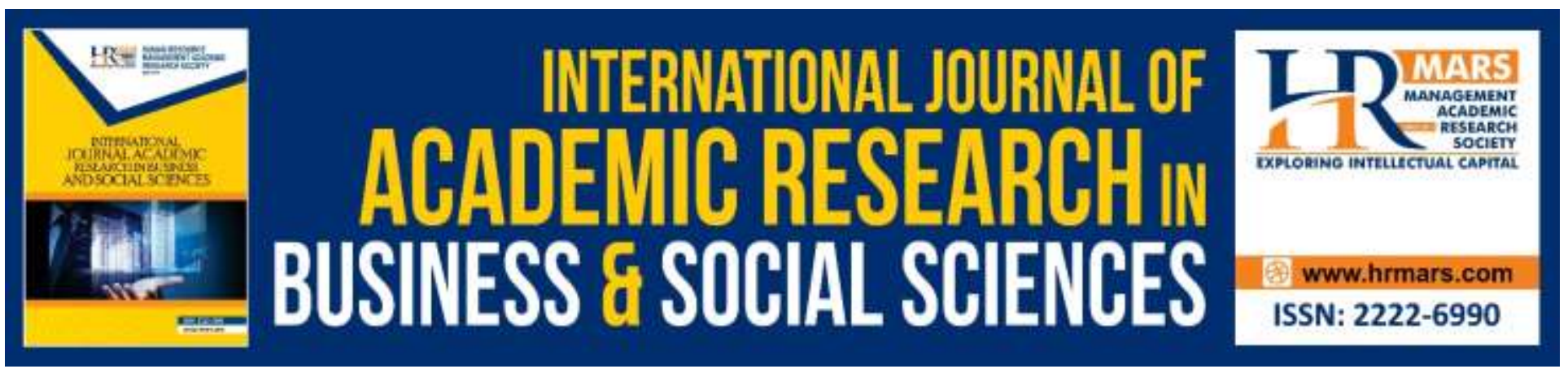

\title{
Self-Employment and Unemployment in Tunisia: Application of the ARDL Approach
}

\author{
Chiraz Feki, Sirine Mnif \\ Department of Economics, Faculty of Economics and Management of Sfax, \\ Email: fekichiraz@yahoo.fr, mnifsirine@hotmail.fr
}

\begin{abstract}
In the literature on the link between entrepreneurship and unemployment, self-employment is the most frequently used indicator for measuring entrepreneurship. The impact of unemployment on self-employment is known as the "refugee effect". Conversely, the impact of self-employment on unemployment is known as the "entrepreneurial effect". The relationship between the unemployment rate and self-employment is rather an ambiguous question in the economy. There are two counter arguments: the first is the theory of income choice argumentation, which suggests that increased unemployment may lead to an increase of self-employment activities, while the second argues that the increase of the unemployment rate may decrease human capital endowments and entrepreneurial capacity, which drives unemployment rates higher. The results of the existing studies are varied. The aim of this study is to determine the dynamic relationship between unemployment and self-employment in Tunisia during the period 1980-2015 using the ARDL (Auto Regressive Distributed Lag) approach. Tunisia supports positive impact of unemployment on selfemployment and supports negative impact of self-employment on unemployment.
\end{abstract}

Keywords: Unemployment, Self-employment, Tunisia, ARDL

\section{Introduction}

Debates about self-employment and unemployment have been paving the way for an increasing number of studies over the past two decades. Oxenfeldt (1943) assumes that people who are involuntarily unemployed, and who have minimal chances of finding a job, with a wage that meets their basic needs, are moving towards the independent labor market which presents a reserve solution for them. In addition, Knight (1921) supports the idea that individuals can be divided into three groups: the first presents the unemployment situation, the second presents the situation of occupation of self-employment and the third situation is that employment. The main contribution of this research corresponds to the valorization of self-employment, as a structural solution to control unemployment rates, and stimulate economic growth based on a model creator of wealth through the encouragement of individual initiative with measures affecting the different economic and social 
aspects. Thus, the measurement of the impact of unemployment on self-employment and vice versa should reveal valuable policy information for policy makers.

In addition, the relation between entrepreneurship and unemployment has always been a subject of debate whether societal or scientific. One view, which is called the "unemployment push", or the "refugee effect", recommends that the opinion to become an entrepreneur is an answer to unemployment or the perception of bleak future of employment prospects. Other opinions are also manifested, namely what is called "Schumpeter effect" or "entrepreneurial effect" supposes that, entrepreneurship has the obvious effect of minimizing unemployment. This point of view supposes a negative relation between the Entrepreneurship and Unemployment, while the point of view mentioned above suggests a positive relationship. Over and above, there is a reverse causality relationship between these two concepts. To this end, the first relationship, being negative, suggests that the choices of individuals to opt for individual initiative through entrepreneurship minimizes unemployment at the macroeconomic level. Whereas, the second relationship supposes that people are moving towards entrepreneurship as a reserve solution following the blockage encountered in the labor market.

Despite the theoretical and empirical support of researchers for the two opinions already mentioned, the latter did not decide on the link between self-employment and unemployment. Therefore, it is interesting to focus on this relationship, and its clarification in order to direct the decisions of governments towards measures stimulating entrepreneurship. Our work is positioned in this approach, using an econometric approach to try to understand the links between these two variables.

For this reason, we used the cointegration procedure of the Auto Regressive Distributed Lag (ARDL) approach to estimate the changes in unemployment and self-employment for Tunisia over the period 1980-2015. Using the delayed data to explain the current situation, we have modeled the dynamic interrelationship between unemployment and entrepreneurship and found that the relationship between these two variables is both positive and negative. Changes in unemployment apparently have a positive effect on following changes in self-employment rates. Meanwhile, changes in selfemployment rates have a negative effect on subsequent unemployment rates. The first effect is stronger than the second. The findings of this study provide some interesting recommendations for public policy. More precisely, they clearly suggest that public policies for job creation and reduce unemployment are well served by focusing on entrepreneurship.

Finally, the working methodology of this article is as follows: the first section will be devoted to the presentation of the reduction of unemployment. In a second part, we present the independent work. In a third section, we focus on the bilateral relationship between self-employment and unemployment. Subsequently, we present in a fourth section a review of the empirical literature relating to the relationship between these two variables. Finally, the fifth section contains suggestions for our own empirical validation.

\section{Unemployment}

The International Labor Organization (ILO) defines unemployed as the number of economically active persons who are unemployed but who are available and are looking for work, including those who have lost their jobs or voluntarily left their job (World Bank 1998). Actually, unemployment is one of 
the main indicators of the economic activity. In fact, unemployment has different forms, structural, cyclical, frictional and classical. However, it can have other forms, such as seasonal, hidden and brutal. In fact, the amplitude of each type is difficult to measure, particularly, because they overlap (Sullivan and Sheffrin 2003).

Currently, Tunisia is facing labor market problems. The unemployment rate in Tunisia rose from $12.44 \%$ in 2007 to $18.88 \%$ in 2011 . There are many explanations for these developments.

The slowdown of the economic activity, the agitated social context, the suspension of industrial projects, including those financed by FDI (Foreign Direct Investment) and the forced re-entry of many Libyan compatriots after the outbreak of the Libyan revolution of 17 February 2011, aggravated the situation of unemployment in Tunisia.

The first slogan raised during the Tunisian revolution was simply Work, Freedom and National Dignity. Work was then one of the first demands of the people. It is useful to say that when Tunisia made 5\% economic growth, there were 491800 unemployed (May 2010), an unemployment rate of $13 \%$. This justifies that the problem of unemployment is not post-revolutionary. One of the primary components of this rate is the unemployment of graduates. Unemployment among university graduates increased from $14 \%$ in 2005 to $32 \%$ in 2010, which is worrying.

The authorities tried to implement employment policies to curb this situation, through massive recruitment measures at the level of public administration, which did nothing but only exacerbated the deficit of the State budget, or through the advantages givers is the private sector, to recruit graduates, such as through permanents contracts (orientation contracts, qualification contracts, adaptation contracts, apprenticeship contracts, solidarity employment contracts, the Karama contract ...).

\section{Self-Employment}

The involvement of entrepreneurship in various contexts of the economy at the international level is becomes more intensive in recent years, given the solutions it presents for certain degrading economic situations observed in the world. However, the definition of this concept does not form until now a consensus between the different researchers. Various definitions in literature on entrepreneurship reflect this complexity (Bosma and Acs, 2009). Entrepreneurship, as a term, has a wide range of definitions. The entrepreneur is defined as a person who organizes, manages and assumes the risks of the business.

Entrepreneurship, as it stands today, was first defined by the Austrian economist Carl Menger (1870), who argued that entrepreneurship can be designated as an activity involving the discovery, the evaluation and exploitation of opportunities, with the aim of introducing new goods and services, new organizational structures, new markets, processes, and materials, by means that did not exist before. Schumpeter's theory of economic development (1912) places entrepreneurs at the center of the capitalist development process.

Entrepreneurs are responsible for innovations (new products, new sources of supply, new production methods and new forms of organization) that open up opportunities for profit but disrupt the system. Successful entrepreneurs are those who earn high profits and attract imitators. Over time, imitation will eliminate the benefits gained by an original innovator and the system will settle to a new equilibrium until it is, in turn, disrupted by another innovation. 
Through a close reading of the literature related to entrepreneurship, we can see that selfemployment is the most commonly used indicator. This indicator measures the level of entrepreneurship in a given country, and also the relationship between unemployment and entrepreneurship, and entrepreneurship and growth. The main reason for using self-employment, as an indicator of entrepreneurship, is a convenience function: all the developed countries communicate data on self-employment, while facilitates the analysis across countries and over time.

Several expressions are used in the designation of self-employment. Self-employment is also referred to as "free-lance work" or "autonomous work". For the cooperation organization and of economic development OECD (2000), independent employment is perceived like a very important source of development of the entrepreneurship and the small company, which represents a potential growth of long-term employment.

According to the international definition, "self-employment is a job the remuneration of which is directly related to the benefit where the owner makes the management decisions affecting the company and therefore is responsible for the good health of the enterprise" (OECD 2000). In this definition, there are notable exceptions, particularly in the case of incorporated business owners who account for a significant share of self-employment in some OECD countries (eg 31, $4 \%$ in the USA in 1998).

Owner-managers are the owners of their businesses and responsible for their management, but from a legal point of view, they are employees in the company. As a general rule, the term "selfemployment" therefore refers to "those who work for their own account" and to "employers". The definition given by Djaowe and Bita (2007) their study specifies that: "Self-employment is based on the following conditions: it is the result of a free choice, it ensures an adequate income for the family and is based on a relationship of dependency and / or subordination and generates income above the benefits that could be received in the event of assistance".

The statisticians of self-employment distinguish three main categories: independent employment without employees, which corresponds to the category of those who "work for their own account"; independent employment with a paid category of the "employers"; and "not remunerated family workers".

High unemployment rates in Europe have justified the introduction of new business start-up schemes. The development of self-entrepreneurs in Germany and France is due to the emphasis placed by the public authorities on the aid to unemployed creators of a sole proprietorship in order to combat unemployment. Although these measures have overall positive effects on the labor market, they nevertheless lead to an increase of the precariousness of self-employed individuals.

\section{Self-Employment and Unemployment}

"At the individual level, the risk of unemployment is likely to have a positive effect on the level of entrepreneurship by reducing the opportunity costs of self-employment" (Audretsch et al. 2002). More specifically, self-employment should have positive effects on economic growth (Manser and Picot 1999; Mnif 2015; Feki and Mnif 2016). The entrepreneurial activities of the self-employed result in the hiring of workers and thus lead to decreases of the unemployment rate. The positive relationship between unemployment and self-employment is known as the "unemployment push" or the "refugee effect". It can be both a positive effect of unemployment on self-employment (the 
"refugee effect") and a negative effect of self-employment on unemployment (the "entrepreneurial effect"). In fact, both possibilities have been theoretically and empirically studied.

Nevertheless, other assumptions can be made. Hence, it is argued that unemployed people are above all those with a lower level of information, skills and capacities to create new businesses. High unemployment rates reduce the likelihood of self-employment (Thurik et al. 2008). Oxenfeldt (1943) also cited that most unemployed people are willing to start new businesses, but face barriers that are mainly related to financing. Moreover, "at the macroeconomic level, unemployment may be associated with an economic recession and a lack of entrepreneurial opportunities" (Audretsch et al. 2004,2002 ). All these opinions lead to assume that a high unemployment rate rots be followed by a low self-employment rate.

Moreover, Schumpeter assumes that the development of entrepreneurship and new start-ups will provide employment opportunities and will indirectly affect the creation of jobs in other existing businesses. However, the lack of experience and low survival rates mean that some of the new startups close in a very short period of time, which has a negative effect on the reduction of unemployment.

Nevertheless, the unemployed do not have sufficient skills and entrepreneurial abilities, which can result in early retirement. On the other hand, an increase in the unemployment rate can lead to a deterioration in the personal wealth of the unemployed, minimizing their chances of becoming selfemployed.

\section{Review of the Empirical Literature}

Different aspects of the "refugee effect" and the "Schumpeter effect" have been discussed and evaluated theoretically and empirically in a masses of researches (Evans and Leighton 1990; AlbaRamirez 1994; Audretsch and Thurik 2000; Audretsch and Als 2002, 2005; Ritsila and Tervo 2002; Baptista and Preto 2007; Glocker and Steiner 2007; Faria et al. 2010; Fairlie 2011; Yu et al. 2014; Aubry et al. 2015). Available empirical studies present similar ambiguities and reflect these two contradictory theories. Some studies have shown that unemployment is associated with growing entrepreneurial activities while others have found that entrepreneurial activity and unemployment are inversely proportional (Thurik 1999). Evans and Leighton (1990) found a positive relationship between unemployment and newly created firms, while Garofoli (1994) and Audretsch and Fritsch (1994) found the opposite.

While, Carree (2002) found no statistically significant relationship between unemployment and the number of companies. In his empirical discussion of the unemployment rates and the start-up activity of new firms, Storey (1991) closes that: "The general consensus is that time series analyses indicate that unemployment is positively associated with the indices of formation of new Companies, while cross-sectional or pooled cross-sectional studies suggest the opposite." Audretsch and Thurik (2000) presented empirical confirmation that increasing the number of business owners diminishes the unemployment rate. They determine an "entrepreneurial effect" for the positive impact of entry of new firms on employment.

In their study about the United States, Highfield and Smiley (1987) found that the evolution in the unemployment rate was associated with an increase in the rate of new business start-ups. In his study about Spain and the USA, Albo-Ramirez (1994) suggest that the duration of unemployment increases 
the likelihood of becoming self-employed. On their part, Evans and Leighton (1990) report that selfemployed workers are more likely to lose their jobs than employees. In their analysis of 23 OECD countries for the period 1974-1994, Audretsch and Thurik (2000) found that the movement towards entrepreneurial activities in the economy leads to a fall of the unemployment rate. They also pointed out that "the growth in the number of entrepreneurs leads to a reduction in the unemployment rate" (Audretsch and Thurik, 2000).

In another study, Picot et al. (1999) found a weak negative relationship between self-employment and unemployment in Canada. Blanchflower and Oswald (1998), however, found that the unemployment rate has negative effects on self-employment. Blanchflower (2000) concluded that there is a negative relationship between the self-employment rate and the unemployment rate in the majority of OECD countries. Thurik, et al. (2008) analyzed the dynamic relationship between selfemployment and unemployment rates for a panel of 23 OECD countries for the period between 1974 and 2002. They found evidence of both the "refugee effect" and the "entrepreneurial effect" and find that the "entrepreneurial effect" is stronger than the "refugee effect".

Therefore, both theoretically and empirically, unemployment has been shown to have an effect on the growth of self-employment, and this leads to a reduction in unemployment. It is essential to clarify the link between self-employment and unemployment, because policies are often based on sound assumptions that should not be ambiguous. The purpose of this paper is to try to remove the ambiguities of the relationship between unemployment and self-employment.

\section{Empirical Analysis}

We will concentrate on the relationship between unemployment and self-employment in Tunisia during the period 1980-2015. Our variables are as follows: UR represents the unemployment rate and SE represents self-employment. UR is taken from IMF (2017) while SE is taken from WDI (2017).

\section{Estimation Techniques Stationarity Test}

The first stage of the econometric analysis is the study of the stationarity of the two time series UR and SE. To make the two series stationary, we use the Augmented Dickey-Fuller (ADF) test. Although the ARDL cointegration technique does not require all the variables to be I(1), it remains important to verify that not all the variables are I(2). The critical F-statistical values computed by Pesaran et al (2001) and Narayan et al (2005) are based on the assumption that all the variables are I(0) or I(1). The results of the ADF test are shown in Table 1 below and show that UR is I(1) and SE is I(0) at 5\% threshold. 
INTERNATIONAL JOURNAL OF ACADEMIC RESEARCH IN BUSINESS AND SOCIAL SCIENCES Vol. 9, No. 7, July, 2019, E-ISSN: 2222-6990 @ 2019 HRMARS

Table 1: Augmented Dickey-Fuller test

\begin{tabular}{|lcc|}
\hline & \multicolumn{2}{c|}{ ADF Statistic } \\
\hline & In level & In first difference \\
UR & -2.735061 & $-6.872384^{* *}$ \\
Critical value 5\% & -2.948404 & -2.951125 \\
Critical value 10\% & -2.612874 & -2.614300 \\
\hline
\end{tabular}

\begin{tabular}{|lc|}
\hline & ADF Statistic \\
\hline SE & In level \\
Critical value 5\% & $-3.266635^{* *}$ \\
Critical value 10\% & -2.948404 \\
\hline
\end{tabular}

$* *$ denote the significance at the threshold of $5 \%$ respectively.

\section{The ARDL Cointegration Technique}

In this study, we use the ARDL cointegration approach to examine the long-term cointegration relationship between the unemployment and self-employment rates. The ARDL cointegration procedure was introduced by Pesaran and Shin (1999) and then extended by Pesaran et al. (2001).

Compared to the cointegration methods, the ARDL cointegration approach has some advantages. On the one hand, and contrary to other cointegration techniques, it does not impose the hypothesis according to which all the variables come from the same order of integration. In other words, this cointegration approach can be applied even if the variables are I(1) or I(0). On the other hand, it is not sensitive to the sample size but is considered more appropriate for a limited number of observations. The ARDL model used in our analysis is expressed as follows:

Case 1: UR is the endogenous variable

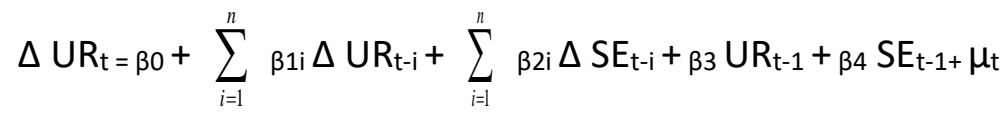

Case 2: SE is the endogenous variable

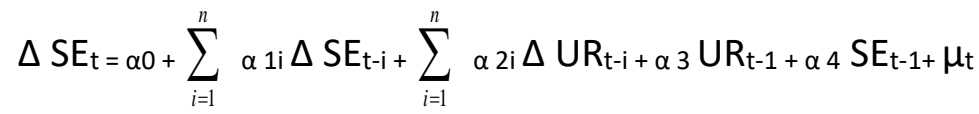

With $\mu$ is the white noise error term and $\Delta$ is the first difference operator. The null hypothesis of non-cointegration in equation (1) states that $(\mathrm{HO}: \beta 3=\beta 4=0)$ against the alternative hypothesis $(\mathrm{H} 1$ : $\beta 3 \neq \beta 4 \neq 0$ ). The null hypothesis of non-cointegration is verified when ( $\mathrm{H0}: \alpha 3=\alpha 4=0)$ against the alternative hypothesis $(\mathrm{H} 1: \alpha 3 \neq \alpha 4 \neq 0)$.

Pesaran and Pesaran (1997) and Pesaran et al. (2001) have fixed for each level of significance two classes of critical values relative to the lower and upper bounds, corresponding to the case where the 
INTERNATIONAL JOURNAL OF ACADEMIC RESEARCH IN BUSINESS AND SOCIAL SCIENCES Vol. 9, No. 7, July, 2019, E-ISSN: 2222-6990 @ 2019 HRMARS

variables are $\mathrm{I}(0)$ and $\mathrm{I}(1)$, respectively. If the calculated statistical value is higher than the upper bounds, hypothesis $\mathrm{HO}$ is rejected and the presence of a long-term cointegration relation is confirmed. However, if the calculated statistical value is lower than the lower bounds of the ARDL test, hypothesis $\mathrm{HO}$ is validated, hence the absence of a long-term cointegration relation. However, if the calculated statistical value is between the two bounds, in this case the cointegration test is judged to be inconclusive and therefore we cannot be interpreted.

The long term relationship between UR and SE is examined using the ARDL cointegration procedure. The first step is to determine the number of delays in equations (1) and (2) based on the Akaike Information Criterion (AIC) and the Schwarz Criterion (SC). Table 2 below shows the optimal number of delays according to the two criteria mentioned above. The optimum number of delays detected corresponds to a delay. The second step is to apply the ARDL bounds value test for equations (1) and (2) in order to detect the existence of long-term relationships between the studied variables. Once one or more long-term relationships are determined, the third step is to estimate this cointegration relationship (see table 4).

Table 2: Determination of the optimum number of delays

\begin{tabular}{|lll|}
\hline & AIC & SC \\
\hline 0 & 7,832 & 7,922 \\
1 & $7,187^{*}$ & $7,459^{*}$ \\
2 & 7,257 & 7,711 \\
3 & 7,385 & 8,020 \\
\hline
\end{tabular}

* denote the significance at the threshold of $10 \%$

Table 3 Detection of the long-term relationship

Case 1: UR is the endogenous variable

\begin{tabular}{|lcccc|}
\hline $\begin{array}{l}\text { Variable with trend and } \\
\text { constant }\end{array}$ & $\begin{array}{l}\text { Nombre of lag } \\
\text { length }\end{array}$ & F-statistic & probability & result \\
\hline UR endogenous & 1 & $5,975^{*}$ & $0,036(5 \%)$ & cointegration \\
\hline
\end{tabular}

\begin{tabular}{|lllllll|}
\hline $\begin{array}{l}\text { Asymptotic critical } \\
\text { values }\end{array}$ & $1 \%$ & \multicolumn{3}{c}{$5 \%$} & $10 \%$ & \\
\cline { 2 - 7 } & $\mathrm{I}(0)$ & $\mathrm{I}(1)$ & $\mathrm{I}(0)$ & $\mathrm{I}(1)$ & $\mathrm{I}(0)$ & $\mathrm{I}(1)$ \\
\hline 36 & 7,593 & 8,350 & 5,377 & 5,963 & 4,427 & 4,957 \\
\hline
\end{tabular}

Case 2: SE is the endogenous variable

\begin{tabular}{|lllll|}
\hline $\begin{array}{l}\text { Variable with trend and } \\
\text { constant }\end{array}$ & $\begin{array}{l}\text { Nombre of lag } \\
\text { length }\end{array}$ & F-statistic & probability & result \\
\hline SE endogenous & 1 & $5,982^{* *}$ & $0,022(5 \%)$ & cointegration \\
\hline
\end{tabular}


INTERNATIONAL JOURNAL OF ACADEMIC RESEARCH IN BUSINESS AND SOCIAL SCIENCES Vol. 9, No. 7, July, 2019, E-ISSN: 2222-6990 @ 2019 HRMARS

\begin{tabular}{|lllllll|}
\hline $\begin{array}{l}\text { Asymptotic critical } \\
\text { values }\end{array}$ & $1 \%$ & \multicolumn{3}{c|}{$5 \%$} & \multicolumn{3}{c|}{} \\
\cline { 2 - 7 } & $\mathrm{I}(0)$ & $\mathrm{I}(1)$ & $\mathrm{I}(0)$ & $\mathrm{I}(1)$ & $\mathrm{I}(0)$ & $\mathrm{I}(1)$ \\
\hline 36 & 6,027 & 6,760 & 4,090 & 4,663 & 3,303 & 3,797 \\
\hline
\end{tabular}

The asymptotic critical values are obtained from Narayan (2005), p. 1987.

Table 4 Estimation of the long-term relationship

Case 1: UR is the endogenous variable

\begin{tabular}{|lll|}
\hline UR endogenous & coefficient & significance \\
\hline Constant & $4,8245^{* *}$ & $5 \%$ \\
\hline SE & $-0,0774^{* *}$ & $5 \%$ \\
\hline
\end{tabular}

$\mathrm{R} 2=0,709$

Case 2: $\mathrm{SE}$ is the endogenous variable

\begin{tabular}{|lll|}
\hline SE endogenous & coefficient & significance \\
\hline Constant & $1,30702^{* *}$ & $5 \%$ \\
\hline UR & $0,0916^{*}$ & $10 \%$ \\
\hline
\end{tabular}

$\mathrm{R} 2=0,709$

\section{Interpretation of the Estimation Results}

According to the results presented in table 4, the effect of unemployment on self-employment is found to positive and significant. We can therefore say that the increase of the unemployment rate leads to the increase of that of self-employment. This shows that the "refugee effect" is verified in Tunisia. Actually, table 4 shows that the effect of self-employment on unemployment is negative and significant. This suggests that an increase in self-employment rate logically leads to the decrease of the unemployment rate. Indeed, both the "entrepreneurial effect" and the "refugee effect" are verified in Tunisia. On the other hand, a solution that can be applied to reduce unemployment in Tunisia is self-employment. For this reason, policies should be directed towards encouraging private investment to be able to control the rise of unemployment in Tunisia, especially after the 2011 revolution.

\section{Conclusion}

The objective of this article was to test the existence of the "refugee effect" and the "entrepreneurial effect" in the case of Tunisia. This objective was achieved through the use of the technique of Pesaran et al. (2001) about the co-integration of the ARDL approach.

Moreover, our work provides new evidence on the relationship between self-employment and unemployment. The results revealed that there is a bi-directional relationship between these two variables in the case of Tunisia. In fact, Tunisia records a positive impact of unemployment on selfemployment and a negative impact of self-employment on unemployment. This suggests that unemployment stimulates the creation of new businesses. These new businesses will then contribute to a reduction in the unemployment rate. We have thus verified the "refugee effect" and the 
INTERNATIONAL JOURNAL OF ACADEMIC RESEARCH IN BUSINESS AND SOCIAL SCIENCES

Vol. 9, No. 7, July, 2019, E-ISSN: 2222-6990 @ 2019 HRMARS

"entrepreneurial effect" in the case of Tunisia. Nevertheless, Tunisia should offer other incentives related to entrepreneurial initiatives to control the rising unemployment and achieve sound and sustainable economic growth.

\section{References}

Alba-Ramirez, A. (1994). Self-employment in the midst of unemployment: the case of Spain and the United States. Applied Economics, 26: 189-204.

Aubry, M., Bonnet, J., \& Renou-Maissant, P. (2015). Entrepreneurship and business cycle: the "Schumpeter" effect versus the "refugee" effect - a French appraisal based on regional data. Annals of Regional Science, 54: 23-55.

Audretsch, D. B. (2008). Does Self-employment Reduce Unemployment? Journal of Business Venturing, 23: 673-686.

Audresch, D. B., \& Fritsch, M. (1994). The geography of firms births in Germany», Regional Studies. 28: 359-365.

Audresch, D. B., \& Thurik, A. R. (2000). Capitalism and democracy in the 21st Century: from the managed to the entrepreneurial economy. Journal of Evolutionary Economics, 10: 17-34.

Audresch, D. B., Carree, M. A., Van Stel, A. J., \& Thurik, A. R. (2005). Does self-employment reduce unemployment?. Scales Paper, 1-16.

Audretsch, D., Thurik, A. R., Verheul, I., \& Wennekers, S. (2002). Entrepreneurship: Determinants and Policy in a European-US Comparison. Kluwer Academic Publishers, Dordrecht.

Audretsch, D. B., Houweling, P., \& Thurik, A. R. (2004). Industry evolution: diversity, selection and the role of learning», International Small Business Journal. 22: 331-348.

Baptista, R., \& Preto, M. T. (2007). The dynamics of causality between entrepreneurship and unemployment», International Journal of Technology, Policy and Management. 7: 215-224.

Blanchflower, D. G. (2000). Self-employment in OECD Countries. Labour Economics. 7: 471-505.

Blanchflower, D. B., \& Oswald, A. J. (1998). What Makes an Entrepreneur ?. Journal of Labor Economics, 16: 26-60.

Bosma, N., \& Acs, J. (2009). Global Entrepreneurship Monitor. Executive Report 2008, Babson University Press, Boston, 125.

Carree, M., Van Stel, A., Thurik, R., \& Wennekers, S. (2002). Economic development and business ownership: an analysis using data of 23 OECD countries in the period 1976-1996. Small Business Economics, 19: 27-290.

Carree, M., Van Stel, A., Thurik, R., \& Wennekers, S. (2007). The relationship between economic development and business ownership revisited. Entrepreneurship \& Regional Development, 19 : 281-291.

Djaowe, J., \& Bita, C. A. (2007). Le rôle des institutions de microfinance dans la création et le développement de la petite entreprise camerounaise. In Tsapi V. (Coord.), Création, développement, gestion de la petite entreprise africaine, Editions CLE, 55-80.

Evans, D. S., \& Leighton, L. (1990). Small Business Formation by Unemployed and Employed Workers. Small Business Economics, 2: 319-330.

Fairlie, R. (2011). Entrepreneurship, economic conditions, and the great recession. IZA Discussion Paper, 5725:1-45. 
INTERNATIONAL JOURNAL OF ACADEMIC RESEARCH IN BUSINESS AND SOCIAL SCIENCES

Vol. 9, No. 7, July, 2019, E-ISSN: 2222-6990 @ 2019 HRMARS

Faria, J. R., Cuestas, J. C., \& Mourelle, E. (2010). Entrepreneurship and unemployment: a nonlinear bidirectional causality? Economic Modelling, 27: 1282-1291.

Feki, C., \& Mnif, S. (2016). Entrepreneurship, technological innovation and economic growth: empirical analysis of panel data. Journal of the Knowledge of Economy, 7, 4.

Garofoli, G. (1994). New firm formation and regional development: The Italian Case. Regional Studies, 28: 381-393.

Glocker, D., \& Steiner, V. (2007). Self-employment: a way to end unemployment? Empirical evidence from German pseudo-panel data. IZA Discussion Paper, 2561: 1-25.

Highfield, R., \& Smiley, R. (1987). New Business Starts and Economic Activity: An Empirical Investigation. International Journal of Industrial Organization, 5:51-66.

Knight, F. H. (1921). Risk, Uncertainty, and Profit. 1964 Edition, New York: Sentry Press.

Manser, M. E., \& Picot, G. (1999). The Role of Self-employment in U.S. and Canadian Job Growth. Monthly Labor Review, April: 1-25.

Mnif, S. (2015). Impact of the Inequalities on the Technological Changes: Case of the Developing Countries. International Journal of Academic Research in Business and Social Sciences, HRmars, 5(3).

Narayan, P. K. (2005). The saving and investment nexus for China: evidence from cointegration tests. Applied Economics, 37: 1979-1990.

Oxenfeldt, A. R. (1943). New Firms and Free Enterprise: Pre-war and Post-war Aspects. American Council on Public Affairs, Washington, D.C.

Pesaran, H. M., Pesaran B. (1997). Microfit 4.0. Oxford University Press.

Pesaran, H. M., Shin, Y., \& Smith, J. R. (2001). Bounds testing approaches to the analysis of relationships. Journal of Applied Econometrics, 16: 289-326.

Ritsila, J., \& Tervo, H. (2002). Effects of unemployment on new firm formation: micro-level panel data evidence from Finland. Small Business Economics, 19: 31-40.

Schumpeter, J. A. (1912). The Theory of Economic Development. New York (NY), Oxford University Press.

Storey, D. J. (1991). The Birth of New Firms does Unemployment Matter. A Review of the Evidence. Small Business Economics, 3:67-178.

Sullivan, A., \& Sheffrin, S. M. (2003). Economics: Principles in Action. Upper Saddle River. New Jersey 07458: Pearson Prentice Hall.

Thurik, A. R. (1999). The Dutch Polder Model: Shifting from the Managed Economy to the Entrepreneurial Economy. Annual meeting of the American Economic Association, New York, N Y. January 3-5.

Thurik, A. R., Carree, M. A., Stel, A. J. Van, \& Audretsch, D. B. (2008). Does Self-Employment Reduce Unemployment? Journal of Business Venturing.

Yu, L., Orazem, P. F., \& Joll, R. W. (2014). Entrepreneurship over the business cycle. Economic Letters, 122: 105-110.

World Bank (1998). World Development Report 1998/1999: Knowledge for Development. Washington, D. C. The World Bank; and New York: Oxford University Press.

World Bank (2017). 2017 World Development Indicators. Data Report, World Bank, Washington. 